\title{
Kisspeptin and the regulation of the reproductive axis in domestic animals
}

\author{
Christopher J Scott ${ }^{1,2}$, Jessica L Rose ${ }^{1,2}$, Allan J Gunn ${ }^{2,3}$ and Briony M McGrath ${ }^{1}$ \\ 1School of Biomedical Sciences, Charles Sturt University, Wagga Wagga, New South Wales, Australia \\ ${ }^{2}$ Graham Centre for Agricultural Innovation, Wagga Wagga, New South Wales, Australia \\ ${ }^{3}$ School of Animal \& Veterinary Sciences, Charles Sturt University, Wagga Wagga, New South Wales, Australia
}

Correspondence should be addressed to C J Scott: chscott@csu.edu.au

\begin{abstract}
The control of reproductive processes involves the integration of a number of factors from the internal and external environment, with the final output signal of these processes being the pulsatile secretion of gonadotrophin-releasing hormone $(\mathrm{GnRH})$ from the hypothalamus. These factors include the feedback actions of sex steroids, feed intake and nutritional status, season/photoperiod, pheromones, age and stress. Understanding these factors and how they influence GnRH secretion and hence reproduction is important for the management of farm animals. There is evidence that the RF-amide neuropeptide, kisspeptin, may be involved in relaying the effects of these factors to the GnRH neurons. This paper will review the evidence from the common domestic animals (sheep, goats, cattle, horses and pigs), that kisspeptin neurons are (i) regulated by the factors listed above, (ii) contact GnRH neurons and (iii) involved in the regulation of $\mathrm{GnRH/gonadotrophin} \mathrm{secretion.}$
\end{abstract}
Key Words
- kisspeptin
- GnRH
- hypothalamus
- domestic animals

Journal of Endocrinology (2019) 240, R1-R16

\section{Introduction}

Brain control of reproduction in mammals involves the integration of a number of factors. In females, these factors impact the ability to attain pregnancy and carry the fetus to term, as well as the ability to suckle the offspring postpartum. Many of these factors also influence reproduction in males. They include gonadal status, as signalled by gonadal hormone secretion, age and body condition of the animals, stressors, pheromones, body rhythms (ultradian, circadian, infradian and circannual) and, in some animals, season/photoperiod. The final output signal of this integration is the release into hypophyseal portal blood of the neurohormone gonadotrophinreleasing hormone $(\mathrm{GnRH})$. Anterior pituitary secretion of the gonadotrophin, luteinising hormone (LH), then acts as an amplifier to the GnRH signal (Clarke \& Cummins 1982). In sheep, at least, the neurons that produce GnRH receive relatively little synaptic input compared to other neurons within the hypothalamus (Lehman et al. 1988, Magee et al. 2009, Decourt et al. 2014, McGrath et al. 2016). Thus, it would seem likely that much of the integration of the various factors that influence GnRH secretion occurs upstream of the GnRH neuron. There is substantial evidence for a wide array of different neurons that regulate GnRH activity, but one particular set of neurons has come to prominence, those that produce kisspeptin. It is a potent regulator of $\mathrm{GnRH}$ and $\mathrm{LH}$ secretion, while there is evidence that all of the factors listed above can influence kisspeptin.

The sheep has proven to be an excellent model for neuroendocrine research and a great deal of research into the regulation and actions of kisspeptin has been conducted using this model. It is clear that in animal production 
systems, reproductive success is critical to the operation of these enterprises, hence, a good understanding of the control of GnRH is necessary. Accordingly, in recent times, this research has spread to other major domestic animal species, especially goats, cattle, horses and pigs, where commonalities have been observed, as well as significant species differences. This review will examine the current state of knowledge regarding kisspeptin neurons in these five species. Firstly, we will examine these neurons and their regulation, then the evidence for their interaction with GnRH neurons, and finally their action on GnRH and/or LH secretion.

\section{Location of Kisspeptin neurons}

The anatomy of the kisspeptin neural network in mammals has been thoroughly reviewed previously (Lehman et al. 2010b). The main population of kisspeptin neurons is in the arcuate nucleus of the hypothalamus, especially in the more caudal region of the nucleus, extending to around the pre-mammillary nucleus. This is well conserved (Table 1), being the case in sheep (Estrada et al. 2006, Franceschini et al. 2006, Goodman et al. 2007), goats (Okamura et al. 2017), cattle (Hassaneen et al. 2016, Tanco et al. 2016), horses (Decourt et al. 2008, Magee et al. 2009) and pigs (Tomikawa et al. 2010).

The second largest population of kisspeptin cells, albeit much smaller in number, is found in the medial preoptic area, in sheep, goats and cattle (Estrada et al. 2006, Franceschini et al. 2006, Goodman et al. 2007, Matsuda et al. 2015, Hassaneen et al. 2016, Tanco et al. 2016). Horses (Decourt et al. 2008, McGrath 2015), by contrast, do not appear to contain kisspeptin neurons in the preoptic area at all. In pigs, the rostral population of kisspeptin neurons is in the periventricular nucleus rather than the preoptic area (Tomikawa et al. 2010). Some cells have also been described in the dorsomedial nucleus and a small number in the ventromedial nucleus in sheep (Franceschini et al. 2006), horses (Decourt et al. 2008) and cattle (Hassaneen et al. 2016).
Nearly all the kisspeptin neurons in the arcuate nucleus co-express neurokinin B and dynorphin (Goodman et al. 2007, Wakabayashi et al. 2010, Hassaneen et al. 2016). They have been branded KNDy (kisspeptin/neurokinin $\mathrm{B} /$ dynorphin) neurons, based on this co-localisation. KNDy neurons have been observed only in the arcuate population and not in other kisspeptin neurons. They form an interactive network (Foradori et al. 2006) and the various roles for kisspeptin, neurokinin B and dynorphin appear critical for their function, as described in detail later. Tract tracing studies in goats (Wakabayashi et al. 2013) have shown extensive communication between the left and right hand sides of the nucleus, mainly via neurokinin B. In sheep (Amstalden et al. 2010) and goats (Wakabayashi et al. 2010), the majority of KNDy neurons express the NK3 receptor, the receptor for neurokinin B, while around $90 \%$ of KNDy neurons in sheep express the kappa opioid receptor, the receptor for dynorphin (Weems et al. 2016). Thus, the KNDy neurons express both the NK3 and kappa opioid receptors. By contrast, kisspeptin neurons do not express the kisspeptin receptor (kiss1R) (Smith et al. 2011), indicating that communication between the KNDy neurons is via neurokinin B and dynorphin but not by kisspeptin. This connection appears to be functional, because central infusion of neurokinin B in anoestrous ewes activated kisspeptin neurons, with a substantial increase in the percentage of kisspeptin neurons expressing the Fos protein, a marker of neuronal activation (Sakamoto et al. 2012). Finally, these KNDy neurons also release glutamate, as evidenced by the presence of the vesicular glutamate transporter protein, vGlut2, in the terminals of KNDy neurons (Merkley et al. 2015).

The distribution of kisspeptin fibres has been described in all the species under consideration (Franceschini et al. 2006, Decourt et al. 2015, Hassaneen et al. 2016, Okamura et al. 2017), except pigs. The distribution appears to be well conserved across species. Notable is a collection of immunoreactive fibres in the external zone of the median eminence, indicating that the kisspeptin peptide is secreted into the portal

Table 1 The location of the main kisspeptin neuronal populations in the brain of domestic animal species.

\begin{tabular}{l} 
Species \\
\hline Sheep \\
Horse \\
Cattle \\
Goat \\
Pig
\end{tabular}

\begin{tabular}{l} 
Region \\
\hline ARC, MPOA \\
ARC \\
ARC, MPOA \\
ARC, MPOA \\
ARC, PVN
\end{tabular}

\section{References}

Estrada et al. (2006), Franceschini et al. (2006), Goodman et al. (2007)

Decourt et al. (2008), McGrath (2015)

Hassaneen et al. (2016), Tanco et al. (2016)

Okamura et al. (2017)

Tomikawa et al. (2010) https://joe.bioscientifica.com

https://doi.org/10.1530/JOE-18-0485 (c) 2019 Society for Endocrinology Published by Bioscientifica Ltd. Printed in Great Britain 
vasculature (Smith 2008). Similarly, in all the species there are abundant fibres in the internal zone, allowing for interaction with fibres of neurons that also secrete into portal vessels (Ohkura et al. 2009b). The arcuate nucleus contains abundant kisspeptin fibres, especially surrounding kisspeptin somata. Kisspeptin fibres are found throughout the septo-preoptic region, which is the region that contains the majority of GnRH neurons (Lehman et al. 1986). Other larger fibre populations include a population running adjacent to, and parallel to the third ventricle.

The kisspeptin fibres found in the median eminence all appear to be of KNDy origin (Smith et al. 2011), indicating that they originate in the arcuate nucleus and not from the other hypothalamic regions. This is confirmed by anterograde tracing studies in ewes, which indicate projections of kisspeptin neurons from the arcuate nucleus to the median eminence (Smith et al. 2011). Similarly, most kisspeptin inputs to the preoptic kisspeptin neurons are also from KNDy neurons (Smith et al. 2011, Merkley et al. 2015).

In sheep, a sex difference has been observed in the kisspeptin neuronal populations. This was first observed for neurokinin B neurons, long before KNDy neurons were discovered (Goubillon et al. 2000), where rams showed fewer neurokinin B immunoreactive (-ir) cells within the caudal arcuate nucleus than observed in ewes. This was subsequently confirmed for KNDy neurons, where rams had nearly half the number of kisspeptin, neurokinin B and dynorphin-positive cells in the arcuate nucleus as did ewes (Cheng et al. 2010). This difference is manifest primarily in the most caudal parts of the arcuate nucleus (Goubillon et al. 2000, Cheng et al. 2010), with little difference in cell numbers in the rostral arcuate. Similarly, significantly higher numbers of kisspeptin-ir neurons were found in the preoptic area of ewes compared with rams (Cheng et al. 2010). Cernea et al. (2015) showed that the sex difference in the KNDy population is most likely due, at least in part, to an organisational action of testosterone, since prenatal treatment of ewe lambs with testosterone resulted in smaller KNDy cells and a reduction in the number of synaptic inputs to KNDy cells, especially KNDy to KNDy connections, as well as the number of inputs to GnRH neurons. This treatment did not reduce the number of kisspeptin cells, however, indicating that testosterone action during development is not the sole reason for the sex difference in the KNDy neuronal population (Cheng et al. 2010).

\section{Regulation of Kisspeptin neurons}

\section{Connections to kisspeptin neurons}

The identity of the neuronal inputs to kisspeptin neurons in domestic animals is summarised in Table 2. Most of what is known has been derived from data in sheep. From immunohistochemical studies, there is evidence of synaptic input to kisspeptin neurons from neurons that produce glutamate (Merkley et al. 2015), dopamine (Goodman et al. 2012), neuropeptide Y (NPY) (Backholer et al. 2010), pro-opiomelanocortin (POMC) (Backholer et al. 2010), melanocyte-stimulating hormone (Cardoso et al. 2015), GnRH (Rose 2017) as well as dynorphin (Weems et al. 2015), neurokinin B (Amstalden et al. 2010, Wakabayashi et al. 2013) and kisspeptin (Goodman et al. 2007). These latter three form the interconnecting network of KNDy neurons mentioned previously. Tract tracing studies show no projections from the rostral preoptic area to the arcuate nucleus (Backholer et al. 2010), indicating no inputs to KNDy neurons from the preoptic population of kisspeptin neurons, a result supported by the work of (Merkley et al. 2015), who showed that virtually all kisspeptin input to KNDy neurons is KNDy.

Table 2 Observed inputs to kisspeptin neurons in domestic species.

\begin{tabular}{|c|c|c|}
\hline Input & Preoptic kisspeptin cells & Arcuate kisspeptin cells \\
\hline Neurokinin B & $X$ & $\checkmark$ \\
\hline Dynorphin & $X$ & $\checkmark$ \\
\hline Glutamate & $\checkmark$ & $\checkmark$ \\
\hline $\mathrm{GnRH}$ & $x$ & $\checkmark$ \\
\hline Dopamine & $X$ & $\checkmark$ \\
\hline Neuropeptide Y & - & $\checkmark$ \\
\hline Pro-opiomelanocortin & - & $\checkmark$ \\
\hline Substance P & $X$ & $\checkmark$ \\
\hline
\end{tabular}

Species Sheep Goat

Sheep Weems et al. (2016)

Sheep Merkley et al. (2015)

Sheep Rose (2017)

Sheep Goodman et al. (2012), Weems et al. (2017)

Sheep Backholer et al. (2010)

Sheep Backholer et al. (2010), Cardoso et al. (2015)

Cattle

Goat Okamura et al. (2017)

$\checkmark$, observed; X, not observed; -, not tested.

https://joe.bioscientifica.com

https://doi.org/10.1530/JOE-18-0485 (c) 2019 Society for Endocrinology Published by Bioscientifica Ltd. Printed in Great Britain 


\section{Kisspeptin regulation by sex steroids}

There is abundant evidence that kisspeptin neurons are regulated by sex steroids. The first evidence for this regulation came from studies of neurokinin B prior to the discovery of kisspeptin. An acute treatment of ovariectomised (OVX) ewes with oestrogen resulted in a reduction in neurokinin B mRNA levels (Pillon et al. 2003). More recent work, conducted primarily in sheep, has provided evidence that kisspeptin neurons are regulated by oestrogen, but in an inhibitory manner by low doses of oestrogen, stimulated by high doses of oestrogen, as well as inhibited by progesterone or testosterone. These are discussed separately below.

\section{Negative feedback actions of oestrogen}

Ovariectomy in ewes resulted in a substantial increase in mRNA expression of the gene for kisspeptin, KISS1, in the arcuate nucleus but not preoptic area (Smith et al. 2007), which was blocked by chronic oestrogen treatment. Similarly, ovariectomy in ewes during the non-breeding season resulted in greater numbers of kisspeptin-ir cells in the arcuate nucleus (but not preoptic area), as well as higher levels of Fos expression within arcuate kisspeptin neurons than in ovary intact ewes. This indicates that ovarian hormones (presumably oestrogen) were inhibiting kisspeptin neurons and their activation (Merkley et al. 2012). Similarly, treatment of adult OVX ewes (Smith et al. 2009b) and ewe lambs (Lopez et al. 2016) with an oestrogen implant during the breeding season resulted in reduced numbers of kisspeptin-ir cells in the arcuate nucleus that expressed Fos protein. Collectively, these results indicate that doses of oestrogen that normally exert a negative feedback action on GnRH secretion inhibit arcuate kisspeptin neurons.

Within KNDy neurons, the nature of this regulation varies between the various neuropeptides produced, with ovariectomy stimulating kisspeptin (Smith et al. 2007), and neurokinin B (Nestor et al. 2012) but inhibiting dynorphin (Foradori et al. 2006) expression. This variability is consistent with the proposed roles of each of these co-localised neuropeptides, as discussed later in this paper. Based on this evidence, though, it would seem likely that sex steroids must change the degree of co-localisation of kisspeptin, neurokinin B and dynorphin (and glutamate) within KNDy neurons (Goodman et al. 2013), but this hypothesis has not been directly tested.

\section{Positive feedback actions of oestrogen}

KISS1 mRNA levels in the arcuate nucleus were elevated during the late follicular phase of the oestrous cycle in the ewe compared with other phases of the cycle (Estrada et al. 2006). This is a time in which circulating oestrogen levels are normally high. This was paralleled by a similar increase in neurokinin B mRNA in mid arcuate kisspeptin neurons at the same stage (Li et al. 2015). Treatment of OVX ewes with an IM injection of oestradiol benzoate, at a dose that reliably induces an LH surge, produced an increase in Fos expression in arcuate kisspeptin neurons, indicating neuronal activation at that time (Smith et al. 2009a). The same study also reported an increase in KISS1 mRNA in arcuate nucleus tissue collected from the late follicular phase of the cycle, compared with the luteal phase. In addition, the number of synaptic inputs to kisspeptin neurons in the arcuate nucleus was higher in oestrous ewes (a time of high circulating oestrogen), compared with ewes in the luteal phase (Merkley et al. 2015). These results suggest that, unlike female rodents, where the evidence strongly points to the arcuate kisspeptin population being negatively regulated by oestrogen and the rostral population being stimulated by higher levels of oestrogen (Smith et al. 2005), the arcuate population is regulated in both a positive and negative manner depending on the circumstances.

The regulation of the kisspeptin neurons at the time of oestrogen positive feedback is less clear. The oestradiol benzoate injection that induced Fos expression in arcuate kisspeptin neurons (vide supra; Smith et al. 2009a) had no effect on the expression of Fos in preoptic kisspeptin neurons. Similarly, the number of kisspeptin-ir neurons in the preoptic area in ewes from the late follicular phase was not different to those during the luteal phase (Smith et al. 2009a), nor was there a difference in the expression of Fos protein in those ewes. In contrast to these studies, however, is a study by Hoffman et al. (2011), which found an increase in Fos expression in the preoptic population of kisspeptin neurons at the start of the preovulatory LH surge in the ewe. Merkley et al. (2015) found an increase in the percentage of preoptic kisspeptin neurons expressing Fos at the time of the LH surge in the ewe. Similarly, KISS1 mRNA expression in the preoptic area also increased in the late follicular phase (Smith et al. 2009a), presumably stimulated by the rising levels of circulating oestrogen. The differences in these studies may reflect the timing of tissue collection, with the negative results coming from those studies where the tissue was collected just prior to the commencement of the LH surge, whilst those studies 
reporting a response to oestrogen used tissue collected after the commencement of the LH surge. Thus, it seems most likely that acute oestrogen positive feedback stimulates preoptic kisspeptin neurons. Nonetheless, more work is needed to clarify the regulation of the preoptic kisspeptin neurons by oestrogen.

In pigs, a reduction in kisspeptin-ir cell number in the arcuate nucleus was observed in brain tissue collected $48 \mathrm{~h}$ after a high dose of oestrogen (around the time of the start of an oestrogen -induced LH surge), but an increase in cell number in the periventricular region (Tomikawa et al. 2010). Similarly, in OVX goats (and castrated males goats), intravenous infusion of oestrogen increased the expression of Fos protein within kisspeptin neurons in the preoptic area but had no effect in the arcuate nucleus (Matsuda et al. 2015). This suggests that the oestrogen regulation of kisspeptin in the pig and goat is more like that of the rat and mouse than in the sheep.

\section{Progesterone}

While much attention has been directed to the regulation of kisspeptin by oestrogen, little attention has been given to the regulation by progesterone. In one sheep study, OVX ewes treated with progesterone had moderately lower KISS1 mRNA levels compared to OVX animals, which was a substantially smaller effect compared with oestrogen treatment (Smith et al. 2007). Progesterone treatment of OVX ewes had no effect on pre-prodynorphin mRNA expression in the arcuate nucleus (Foradori et al. 2005), which we now know would have included KNDy neurons. These results need to be interpreted with caution, however, because oestrogen is needed to upregulate progesterone receptors in the arcuate nucleus (Scott et al. 2000a) and so there may have been insufficient progesterone receptors to allow progesterone to have much of an effect. Thus, the evidence regarding progesterone action on KNDy neurons in sheep is poor. Two studies in cattle (Hassaneen et al. 2016, Tanco et al. 2016) compared kisspeptin cell numbers between cows in the luteal and late follicular phases. Both found higher numbers in the follicular phase than luteal phase, but Hassaneen et al. (2016) found this difference in the preoptic kisspeptin population, while Tanco et al. (2016) found their difference in the arcuate kisspeptin cells. The study by Hassaneen et al. (2016) observed differences in both circulating oestrogen and progesterone levels, with the authors considering that the difference is most likely to be due to oestrogen. By contrast, the study by Tanco et al. (2016) found that circulating oestrogen levels were similar in both groups, while there was a significant difference in progesterone levels, suggesting that it is progesterone having the main action, to inhibit kisspeptin expression in the arcuate nucleus. Preoptic kisspeptin expression was low in that study and did not differ between stages of the oestrous cycle.

\section{Testicular hormones}

There has been little work into the sex steroid regulation of kisspeptin in males of domestic animals. Very few kisspeptin-ir cells could be detected in intact rams (Nestor et al. 2012, Rose 2017) or bucks (Matsuyama et al. 2011), but large numbers of kisspeptin-ir cells were observed in the caudal arcuate nucleus in males that had been castrated (Matsuyama et al. 2011, Nestor et al. 2012, Rose 2017). Thus, testosterone appears to exert a very strong inhibitory action on kisspeptin neurons in male sheep.

\section{Steroid receptors}

Studies in sheep using intracranial implants of sex steroids (Blache et al. 1991, 1996, 1997, Scott et al. 1997, Caraty et al. 1998) indicate that in both males and females, the arcuate nucleus, and to a lesser extent the preoptic area are key sites for the actions of sex steroids in the hypothalamus. Thus, the sex steroids may act directly on kisspeptin neurons. In the ewe, around half of preoptic kisspeptin neurons expressed oestrogen receptor alpha $(E R \alpha)$, but virtually all kisspeptin neurons in the arcuate nucleus expressed ER $\alpha$ (Goubillon et al. 2000, Franceschini et al. 2006), progesterone receptors (Foradori et al. 2002, Dufourny et al. 2005, Smith et al. 2007) and/or androgen receptors (Rose 2017). Arcuate kisspeptin neurons in rams also express ER $\alpha$ and AR (Rose 2017). We also have preliminary evidence for the expression of ER $\alpha$ in the kisspeptin neurons of cattle (Rose et al. 2018). The situation in the horse, goat and pig is unknown.

The expression of oestrogen receptor beta (ER $\beta$ ) within kisspeptin neurons has not been studied in domestic animals. Since there is no ER $\beta$ in the arcuate nucleus of the sheep (Scott et al. 2000b), ER $\beta$ is unlikely to be expressed by KNDy neurons. There is, however, abundant ER $\beta$ expression in the preoptic area and so expression within preoptic kisspeptin neurons is possible. Since there is little evidence for an action of oestrogen in the preoptic area to regulate LH secretion in sheep (Blache et al. 1991, Scott et al. 1997), such co-expression is unlikely to be physiologically significant.

\section{Puberty}

One study in pigs (Ieda et al. 2014) found that KISS1 mRNA levels in the arcuate nucleus did not change 
across puberty. By contrast, there is evidence that, in the sheep, kisspeptin expression increases across puberty. KISS1 mRNA levels in the preoptic area increased across the early stages of puberty in OVX ewe lambs treated with oestrogen (Redmond et al. 2011a). In the same study, KISS1 mRNA levels in the arcuate nucleus were not significantly different across the ages examined, but there was a significant correlation between the number of KISS1-expressing cells and the frequency of LH pulses, suggesting an association with puberty. Another study found the number of kisspeptin-ir cells was higher in post-pubertal ewe lambs (but not in ram lambs) in the arcuate nucleus (Nestor et al. 2012), while they found too few kisspeptin-ir cells in the preoptic area to quantify. These two studies differ in results, which might reflect both the differences in the techniques used, and the age of the animals used in the two studies (age of animals vs pre- and post-puberty). They do, however, agree in the final conclusion, that, in the ewe, changes in kisspeptin expression are associated with puberty. Further work is required to clarify the nature of this association.

\section{Season/photoperiod}

Many species of domestic animal have clear seasons of reproductive activity with polyoestrous cyclicity and sperm production coupled with periods of reproductive quiescence. An understanding of the systems that control this seasonal breeding is essential in order to manage reproduction and productivity from these species. The idea that kisspeptin neurons are regulated by season/photoperiod was first mooted by Smith et al. (2007), when they observed that the number of KISS1 mRNA-containing cells was higher in the arcuate nucleus in sheep during the breeding season than during the non-breeding season. No such seasonal difference was observed in the preoptic population of kisspeptin neurons. A subsequent study (Smith et al. 2008a) found a similar difference in the number of kisspeptin-ir cells in the middle and caudal arcuate nucleus. The same result was also observed in Abadeh goat does (Jafarzadeh Shirazi et al. 2014) and in the mare (McGrath 2015), even though the mare is a long-day breeder, whilst sheep and goats are short-day breeders. These differences in kisspeptin cell number were matched by changes in neurokinin B cell number but not dynorphin in OVX ewes treated with oestrogen implants (Weems et al. 2017), indicating a seasonal change in the degree of co-localisation in KNDy neurons and presumably therefore the way they function. Notably, though, the changes in cell numbers for kisspeptin, neurokinin B and dynorphin in this study differed between ewes that were OVX and then treated with oestrogen implants and those that were OVX but without the implants. In OVX ewes, the number of kisspeptin and neurokinin B-ir cells in the arcuate nucleus was in fact lower in the breeding season than non-breeding season, (the opposite to that observed in OVX ewes treated with oestrogen (Weems et al. 2017). This indicates a seasonal shift in the nature of the actions of oestrogen to regulate KNDy neurons.

These seasonal differences are likely to be photoperiod driven, since transferring ewes from an artificial long-day (inhibitory) photoperiod to short days resulted in a higher number of kisspeptin neurons in the arcuate nucleus (Chalivoix et al. 2010), while ewes housed in short day photoperiod had higher levels of KISS1 mRNA in the arcuate nucleus compared with ewes housed in longer photoperiods (Wagner et al. 2007).

Kisspeptin neurons in the ewe do not appear to express melatonin receptors (Li et al. 2011), suggesting that any action of melatonin to mediate the photoperiod signals to kisspeptin neurons is likely to be indirect. In sheep, dopamine neurons in the retrochiasmatic area of the hypothalamus exert an inhibitory effect on GnRH secretion during anoestrus, but not during the breeding season (Goodman et al. 2010). These neurons project to the arcuate nucleus (Goodman et al. 2010), and the kisspeptin neurons express dopamine D2 receptors (Goodman et al. 2012). This expression is seasonally regulated, twice as many KNDy neurons expressing this receptor in the nonbreeding season (80\%) as in the breeding season (40\%) (Goodman et al. 2012). Thus, in the ewe, part of the inhibitory actions of photoperiod on kisspeptin may be via the dopamine neurons of the retrochiasmatic area.

There is now abundant evidence that thyroid hormones exert a strong influence in synchronising seasonal reproduction in a number of species, including sheep (Webster et al. 1991, Thrun et al. 1997), particularly in timing the onset of the transition from polyoestrous cyclicity to anoestrus. Part of this action may involve local conversion from thyroxine to tri-iodothyronine by type 2 deiodinases within the mediobasal hypothalamus (Yasuo et al. 2006). The activity of this enzyme increases with the transition to an inhibitory photoperiod in sheep (Hanon et al. 2008). Virtually all KNDy and preoptic kisspeptin neurons express thyroid receptor $\alpha$ although this expression does not change with season (Dufourny et al. 2015). While the expression of thyroid receptors in kisspeptin neurons may reflect the general metabolic actions of thyroid hormones, it is possible that this is 
another pathway by which season/photoperiod regulates kisspeptin neurons.

\section{Nutrition and food intake}

Nutritional status influences reproduction through alterations in GnRH/LH secretion (De Bond \& Smith 2014). An understanding of this is of critical importance for animal production in order to maximise reproductive outputs such as ovulation and conception rates, and a great deal of research has been conducted in this area (Chagas et al. 2007, Martin et al. 2010). GnRH neurons receive direct inputs from neuronal systems associated with metabolic status, such as NPY, POMC (first order orexigenic and anorexigenic neurons respectively) and orexin (Norgren \& Lehman 1989, Iqbal et al. 2001, Jansen et al. 2003, Goodman et al. 2004), allowing for direct regulation of GnRH secretion. The role of kisspeptin in relaying the influence of nutritional status on the reproductive system is unclear, and given this importance of understanding the role of nutrition in reproductive function in domestic animals it is surprising that there has not been more research conducted in this area. In one study (Backholer et al. 2010), lean sheep had lower KISS1mRNA levels in both the preoptic area and arcuate nucleus compared with control-fed ewes. This effect was reversed with intracerebroventricular (ICV) leptin infusion. This could be a direct effect of leptin on kisspeptin neurons since the same study also found the leptin receptor expressed in virtually all kisspeptin neurons in both the arcuate nucleus and preoptic area. By contrast, another sheep study (Louis et al. 2011) reported no phosphorylation of STAT, a marker of direct leptin receptor activation, in preoptic and arcuate kisspeptin neurons following leptin infusion, which suggests that kisspeptin neurons do not express the kisspeptin receptor. This difference may reflect the sensitivity of the techniques used. Backholer et al. (2010) used single cell laser microdissection, coupled with real-time PCR, which would be more sensitive than the immunohistochemistry used by Louis et al. (2011). Thus, it is possible that the leptin receptor is present but only expressed to a small degree. Nonetheless, there is good evidence for indirect signalling of nutritional status. Kisspeptin neurons in the arcuate nucleus of the ewe receive inputs from NPY neurons and POMC (Backholer et al. 2010) and ICV administration of an agonist to the POMC system increased KISS1 mRNA expression in preoptic neurons (Backholer et al. 2009). Similarly, high food intake increased the percentage of kisspeptin neurons receiving apposition from fibres in heifers that were immunoreactive for the POMC product, $\alpha \mathrm{MSH}$ (Cardoso et al. 2015). Thus, the signals of nutritional status could be relayed to kisspeptin neurons via any or all of these neuronal systems.

\section{Stress}

Stressors are of great importance to domestic animal production systems, as some can have significant inhibitory actions on reproduction (Tilbrook et al. 2002, Einarsson et al. 2008), whilst some acute stress can actually stimulate reproduction, especially in pigs (Einarsson et al. 2008) and an understanding of this is important for animal management. Evaluation of stress effects on the reproductive system is difficult because the effects may vary with the type of stressor employed and the reproductive status of the animals (Tilbrook et al. 1999). Most work in this area has been conducted in sheep and pigs. There is strong evidence that some stressors, such as heat, transport isolation/restraint, barking dog, hypoglycaemia and lipopolysaccharide injection can inhibit reproduction, at least in part via an inhibition of GnRH secretion (Tilbrook et al. 2002, Einarsson et al. 2008). Part of this is through cortisol, acting via the type II glucocorticoid receptor (Ralph et al. 2016). GnRH neurons themselves do not express this receptor (Dufourny \& Skinner 2002), but KNDy neurons do (unpublished data cited by Ralph et al. 2016). Further unpublished data cited by Ralph et al. (2016) showed that stress-like levels of cortisol increased pre-prodynorphin mRNA levels in the arcuate nucleus of ewes, compared with control animals. Lipopolysaccharide injection reduced the expression of Fos protein in kisspeptin cells in the arcuate nucleus observed at the time of the preovulatory LH surge (Fergani et al. 2017), indicating reduced activation of the kisspeptin neurons at this time due to the stress of the toxin. The role of stress in the regulation of preoptic kisspeptin neurons in domestic animals does not appear to have been tested.

\section{Pheromones}

In female sheep and goats, the presence of a novel male induces a rapid increase in the frequency of GnRH/LH pulses and thence ovulation, especially late in the anoestrous period (Hawken \& Martin 2012). This phenomenon, known as the 'ram effect' in sheep, is used in some sheep production systems for flock management and accordingly important to understand fully. It is considered to be primarily an olfactory signal, although the pathway(s) to the GnRH neurons 
are poorly understood (Delgadillo et al. 2009). In anoestrous ewes, the ram effect resulted in an increase in KISS1 mRNA in the rostral and mid-arcuate nucleus, but, surprisingly not the caudal arcuate (De Bond et al. 2013). It also resulted in an increase in the percentage of kisspeptin neurons that express Fos. Studies in OVX goats, have measured electrical activity in the region of the KNDy neurons (multi-unit activity; MUA). These have demonstrated bursts of electrical activity known as volleys and the timing of these volleys are coincident with pulses of LH secretion (Ohkura et al. 2009a, Murata et al. 2011). Hair from bucks (known to contain high levels of pheromones) induced an increase in MUA volleys, which were suppressed by the neurokinin B (NK3) receptor antagonist SB22200 (Sakamoto et al. 2013). Whilst the 'male effect' is known to also work in pigs (Kirkwood et al. 1981), there has been no published work considering the role of kisspeptin in its action in this species. Nonetheless, the evidence suggests that in sheep and goats, olfactory cues from novel males can exert an effect on the activity of kisspeptin neurons.

\section{Conclusion}

The use of neuroanatomical data to draw conclusions about physiological function, needs to be done with caution, as correlations do not necessarily mean causation. An increase in cell numbers and levels of mRNA expression does not necessarily mean increased cell activity, nor does the absence of changes in cell number or mRNA expression mean no change in cell activity. Nonetheless the evidence is strong that kisspeptin neurons in the arcuate nucleus are regulated by a wide range of factors from the internal and external environment in domestic animals. There is less evidence for regulation of the more rostral kisspeptin population.

\section{Connections of Kisspeptin neurons}

A number of neurons receive close contact by fibres containing kisspeptin, suggestive of synaptic input. In sheep, these include NPY and POMC (Backholer et al. 2010). Most attention, however, has been directed to GnRH (summarised in Table 3), where cell bodies and dendrites have received close contacts from kisspeptin fibres in sheep (Smith et al. 2008a, Lehman et al. 2010b), horses (Magee et al. 2009) and cattle (Tanco et al. 2016). There appear to be fewer inputs to GnRH cell bodies and dendrites in goats (Matsuyama et al. 2011). The situation in pigs is unknown.

The input to GnRH neurons was considered most likely kisspeptin itself, rather than by neurokinin B. GnRH neurons in sheep express kiss1R (Smith et al. 2011, Li et al. 2012), but they do not express the neurokinin B receptor (NK3) (Amstalden et al. 2010, Ahn et al. 2015). Surprisingly, GnRH neurons in sheep also express the kappa opioid receptor (Weems et al. 2016), indicating that dynorphin can act directly on GnRH neurons. It is not clear whether this reflects an action of KNDy neurons on GnRH neurons via dynorphin or the means by which non-KNDy dynorphin neurons regulate GnRH secretion. Further work is required to address this issue.

Close contacts have been observed between fibres that produce GnRH and kisspeptin in the median eminence of sheep (Lehman et al. 2010a), goats (Matsuyama et al. 2011), horses (Decourt et al. 2008) and cattle (Ohkura et al. 2010). These contacts were observed in the absence of the expression of synaptophysin, suggesting that there are no synaptic modifications to the membrane and hence it is likely that kisspeptin is regulating GnRH neurons in a non-synaptic manner (Matsuyama et al. 2011).

The number of GnRH neurons with inputs from kisspeptin fibres varies with season in sheep

Table 3 Observed inputs of kisspeptin fibres to GnRH neurons \& fibres in domestic species.

\begin{tabular}{|c|c|c|}
\hline & Species & Reference \\
\hline \multicolumn{3}{|l|}{ GnRH cells } \\
\hline & Sheep & Smith et al. (2008a), Lehman et al. (2010b), Li et al. (2012), Merkley et al. (2015) \\
\hline & Goat & Matsuyama et al. (2011) \\
\hline & Horse & Decourt et al. (2008), Magee et al. (2009) \\
\hline & Cattle & Tanco et al. (2016) \\
\hline & Pig & Not tested \\
\hline \multicolumn{3}{|c|}{ GnRH fibres in median eminence } \\
\hline & Sheep & Lehman et al. (2010b), Smith et al. (2011), Merkley et al. (2015) \\
\hline & Goat & Matsuyama et al. (2011) \\
\hline & Horse & Decourt et al. (2008) \\
\hline & Cattle & Ohkura et al. (2010) \\
\hline & Pig & Not tested \\
\hline
\end{tabular}


(Smith et al. 2008a), with a greater percentage of GnRH-ir cells in the mediobasal hypothalamus receiving kisspeptin input in the breeding season than the nonbreeding season in OVX ewes treated with oestrogen. By contrast, we (McGrath 2015) found no season difference in the proportion of GnRH neurons that were apposed by kisspeptin fibres in the mare, comparing non-breeding season, vernal transition and breeding season.

An alternative means by which kisspeptin could influence the reproductive system is at the anterior pituitary gland to influence gonadotrophin secretion. Kisspeptin has been measured in hypophyseal portal blood from OVX ewes, albeit at low levels (Smith et al. $2008 b$ ). Furthermore, gonadotrophs from ewes express the kiss1 receptor (Smith et al. 2008b). Thus, while the only available information for domestic animals is from sheep, the evidence is that kisspeptin can make contact with, and influence gonadotroph function.

In summary, kisspeptin neurons are well placed to influence gonadotrophin secretion, as they make contact with GnRH neurons at the cell bodies, dendrites and terminals, as well as, in an endocrine manner, directly with gonadotrophs. Thus, they are in a position to influence GnRH and/or LH secretion. Whether they do so is discussed in the next section.

\section{Kisspeptin regulation of the hypothalamo-pituitary-gonadal axis}

Most research into kisspeptin in domestic animals has centred on its ability to influence LH secretion. Almost all of this research has been conducted in females, with very little research centred on the role of kisspeptin in the regulation of LH secretion in males. The quantity of research in this area is substantial, and it is not possible for an exhaustive review of all relevant studies. A number of excellent reviews have more than adequately covered this material, including (Caraty et al. 2010, Caraty et al. 2012, Okamura et al. 2013).

The kisspeptin peptide can be detected in several forms, from 10-54 amino acids in length, but the biological activity appears to reside in the last 10 amino acids of the C terminal (Gottsch et al. 2004). It is this 10 amino acid fragment that is used for almost all studies on the actions of kisspeptin. Single intravenous (IV) bolus treatment of kisspeptin has increased plasma LH in females from all the species under consideration - sheep (Caraty et al. 2007), goats (Hashizume et al. 2010), horses (Magee et al. 2009), cattle (Kadokawa et al. 2008) and pigs (Lents et al. 2008).

(C) 2019 Society for Endocrinology Published by Bioscientifica Ltd. Printed in Great Britain
Longer IV infusions have also stimulated LH secretion in ewes (Caraty et al. 2007) and mares (Decourt et al. 2014, McGrath et al. 2016). IV kisspeptin also increased plasma LH in male goats (Saito et al. 2012) and bull calves (Ezzat et al. 2009), as well as testosterone in stallions (Akhtar et al. 2017). Surprisingly, little other research has been conducted on the actions of kisspeptin in males of domestic animals.

The action of kisspeptin to stimulate LH secretion is likely to be at one of three places; stimulating GnRH secretion through actions at the GnRH neurons in the preoptic area or arcuate nucleus (cell bodies, dendrites or dendrons), on GnRH terminals in the median eminence, or stimulating LH secretion directly in the pituitary gland. This can be to influence the generation of $\mathrm{GnRH} / \mathrm{LH}$ pulses as well as the preovulatory GnRH/LH surge. The evidence for each is discussed in turn.

\section{Kisspeptin action at the pituitary gland}

Studies using primary pituitary cell cultures from ewes (Smith et al. 2008b), male calves (Suzuki et al. 2008) and barrows (Suzuki et al. 2008) have demonstrated that kisspeptin can directly stimulate LH secretion from pituitary cells. On the other hand, kisspeptin was unable to influence the $\mathrm{LH}$ response to $\mathrm{GnRH}$ in ewes that had undergone hypothalamo-pituitary disconnection, to isolate the pituitary gland from the influence of the hypothalamus (Smith et al. 2008b). This gives reason to question whether the capability of kisspeptin to act at the pituitary gland is of physiological importance, at least in the ewe.

\section{Kisspeptin action on GnRH secretion}

There is strong evidence that kisspeptin regulates GnRH secretion. IV kisspeptin injection increased $\mathrm{GnRH}$ secretion in hypophyseal portal blood in ewes (Smith et al. 2011, Caraty et al. 2013) and OVX goats (Tanaka et al. 2012). Similarly, IV (Caraty et al. 2007) or ICV (Messager et al. 2005) kisspeptin treatment in ewes produced an increase in GnRH secretion in cerebrospinal fluid (CSF), with a parallel rise in plasma LH concentrations. Thus, kisspeptin stimulates GnRH secretion, at least in sheep and goats. The question is whether this is an action at or near the GnRH cell bodies or the terminals. The anatomical evidence is that either or both are possible (vide supra). A large IV bolus injection of kisspeptin in ewes increased kisspeptin levels in peripheral blood but not in CSF (Caraty et al. 2013). This indicates that IV kisspeptin does 
not cross the blood brain barrier. As such, it is unlikely to act on or near GnRH cell bodies or dendrites, although it is still able to act on GnRH terminals in the median eminence. Indeed, there is good evidence for kisspeptin action in the median eminence. Kisspeptin stimulated GnRH release from cultured median eminence explants from OVX ewes (Smith et al. 2011), and microinjection of kisspeptin into the median eminence in vivo stimulated a pulse of LH secretion in OVX ewes (Ezzat et al. 2015). In addition, in a study using anaesthetised animals, which precludes a central action, IV kisspeptin treatment of OVX ewes still increased LH secretion (Ezzat et al. 2015).

Whilst IV kisspeptin treatment is unlikely to act on GnRH cell bodies or dendrites to stimulate GnRH secretion, this does not prevent endogenous kisspeptin from acting in this way, and ICV kisspeptin, which also stimulates LH secretion in sheep (Messager et al. 2005) and pigs (Lents et al. 2008), could act at this site. The anatomical evidence for contact between kisspeptin fibres and GnRH cell bodies and the presence of kiss1R on GnRH cells (vide supra) indicates that an action of kisspeptin on GnRH cell bodies/dendrites would seem likely. The best evidence from domestic animals probably comes from studies using the 'ram effect' (De Bond et al. 2013). Pulsatile GnRH/LH secretion in anoestrous ewes rapidly increases following exposure to a novel ram. Such an exposure induced Fos protein in both kisspeptin and GnRH neurons, indicating that both kisspeptin and GnRH neurons were activated by this event. This would not have happened if it were purely an action on GnRH terminals.

\section{GnRH pulse generator}

GnRH secretion is pulsatile in nature (Clarke \& Cummins 1982) and a great deal of research has been undertaken to determine the source of this pulsatile activity; the so-called GnRH pulse generator. There is evidence that the network of KNDy neurons contributes to GnRH pulse generation and might even be the GnRH pulse generator. Early evidence for this hypothesis is described by Lehman et al. (2010a) and proposes that synchronous activity of KNDy neurons involves the coordinated activity of neurokinin B and dynorphin, with the output signal to the GnRH neurons being kisspeptin. The signal to stimulate a GnRH pulse is initiated by neurokinin B activity within the KNDy neuron network, while dynorphin acts to cease kisspeptin release from the KNDy neurons, which acts to end GnRH pulses. The anatomical evidence described above, whereby KNDy neurons express both the neurokinin B receptor (NK3R) and the dynorphin receptor
(Kappa opioid receptor) but not the kiss $1 \mathrm{R}$, supports this hypothesis, as does evidence that Kappa opioid receptors are internalised at the time of $\mathrm{GnRH} / \mathrm{LH}$ pulses (Weems et al. 2018).

In vivo electrophysiological studies conducted in goats provide a good model in which to test these hypotheses. Electrodes implanted into the mediobasal hypothalamus, the home to the KNDy neurons, consistently record volleys in electrical activity (MUA), as described earlier in this paper. They are considered to reflect the activity of the KNDy neuronal network although these cannot be directly determined. Nonetheless, these increases in activity consistently coincide with pulses in LH secretion in OVX goats (Ohkura et al. 2009b, Wakabayashi et al. 2010, Sakamoto et al. 2013), are identical in size and shape on both sides of the brain and have been termed GnRH pulse generator activity. IV kisspeptin treatment to OVX goats increased LH pulses with no change to MUA, suggesting that the source of the MUA is upstream of kisspeptin action (Ohkura et al. 2009b). Central (ICV) infusion of dynorphin decreased MUA volleys (and LH pulses), while neurokinin B induced volleys in MUA, suggesting that neurokinin $B$ and dynorphin are involved in generating a rhythmic discharge of kisspeptin (Wakabayashi et al. 2010). Conversely, central infusion of a neurokinin B antagonist blocked pheromone-induced increases in MUA volleys, whilst blocking pulsatile LH secretion, suggesting that communication between the KNDy cells is needed for MUA volleys and LH secretion (Sakamoto et al. 2013). Similarly, following suppression of LH secretion with kisspeptin receptor disruption in OVX goats, male pheromones or treatment with the neurokinin B agonist senktide, which normally stimulate LH pulses, induced MUA volleys but no increase in LH pulses (Yamamura et al. 2014). This suggests actions upstream of the final kisspeptin output. In support of these results are studies conducted in ewes (Goodman et al. 2013, Porter et al. 2014, Li et al. 2015), where kiss1R or neurokinin B receptor (NK3R) antagonists blocked LH pulses, suggesting a stimulatory role for those receptors, whilst neurokinin B itself, other NK3R agonists or a dynorphin antagonists stimulated LH pulses.

An alternate hypothesis, which is not mutually exclusive of the hypothesis of the KNDy neuronal network as the GnRH pulse generator, is that there is inherent pulsatility in GnRH neurons themselves, which just needs tuning. Evidence for this in sheep comes from a study where LH pulsatility was blocked in OVX ewes by treatment with an NK3R antagonist, and then restored with an IV infusion of kisspeptin (Clarke et al. 2018). 
In that study, the KNDy neuronal network was effectively shut down, yet constant delivery of kisspeptin reactivated LH pulses. This argues that there is pulse generation capacity upstream of the kisspeptin receptor. It is possible that there is GnRH pulse generation capacity in both the KNDy neurons and GnRH neurons and that they can work together or independently, but more work is required to understand the true nature of the so-called GnRH pulse generator.

\section{Kisspeptin regulation of the LH surge and ovulation}

The role of kisspeptin in the regulation of preovulatory surge of LH appears to vary with species, which may relate to the varying nature of the LH surge. In sheep, a preovulatory-like LH surge can be easily and reliably produced in anoestrous or OVX ewes with a single injection of oestradiol benzoate (Wright \& Clarke 1988), with an LH surge commencing 12-15 h later. Preovulatory LH surges can likewise be generated in progesterone pretreated ewes with IV infusions of kisspeptin for 30-48 h in anoestrous ewes, and in even less time in ewes during the breeding season (Caraty et al. 2007, Sébert et al. 2010). This is most likely not the direct generation of an LH surge, but an increase in GnRH/LH pulses, which stimulates the ovary, leading to an LH surge stimulated by endogenous oestrogen (Sébert et al. 2010). Similarly, hourly kisspeptin injections for $24 \mathrm{~h}$ in lambs triggered an LH surge and ovulation (Redmond et al. 2011b). Meanwhile, ICV treatment with kisspeptin antagonist p-271 attenuated the size of an oestrogen-induced LH surge (Smith et al.
2011). Collectively, these results strongly indicate a role for kisspeptin in the generation of the LH surge in sheep, but this latter result, where the LH surge was attenuated, but not blocked completely, indicates that kisspeptin is not solely responsible for the generation of the LH surge.

The LH surge in horses is more complex, developing slowly over several days (Geschwind et al. 1975) and ovulation is hard to induce clinically (Norman \& Larsen 2010). It is perhaps therefore not surprising that providing evidence for a role of kisspeptin in the LH surge has proven more challenging. A single IV injection of a large dose of kisspeptin $(10 \mathrm{mg})$ did advance ovulation in mares with large ovarian follicles (Briant et al. 2006). Lower doses of kisspeptin, however, whether as bolus injections or continuous infusions, up to 9 days in length and across a range of doses, all increased circulating LH concentrations, but failed to induce an LH surge (Magee et al. 2009, Decourt et al. 2014, McGrath et al. 2016), whether in cycling mares, anoestrous mares or those in vernal transition. Thus, the role that kisspeptin plays in the generation of the LH surge in horses is not clear. Considering that experiments using the same model that consistently induced an LH surge in sheep failed to induce one in horses, this indicates that the role of kisspeptin in horses differs from that in sheep.

\section{Conclusion}

A model that integrates this data is illustrated in Fig. 1. Whilst there are both species and sex differences,

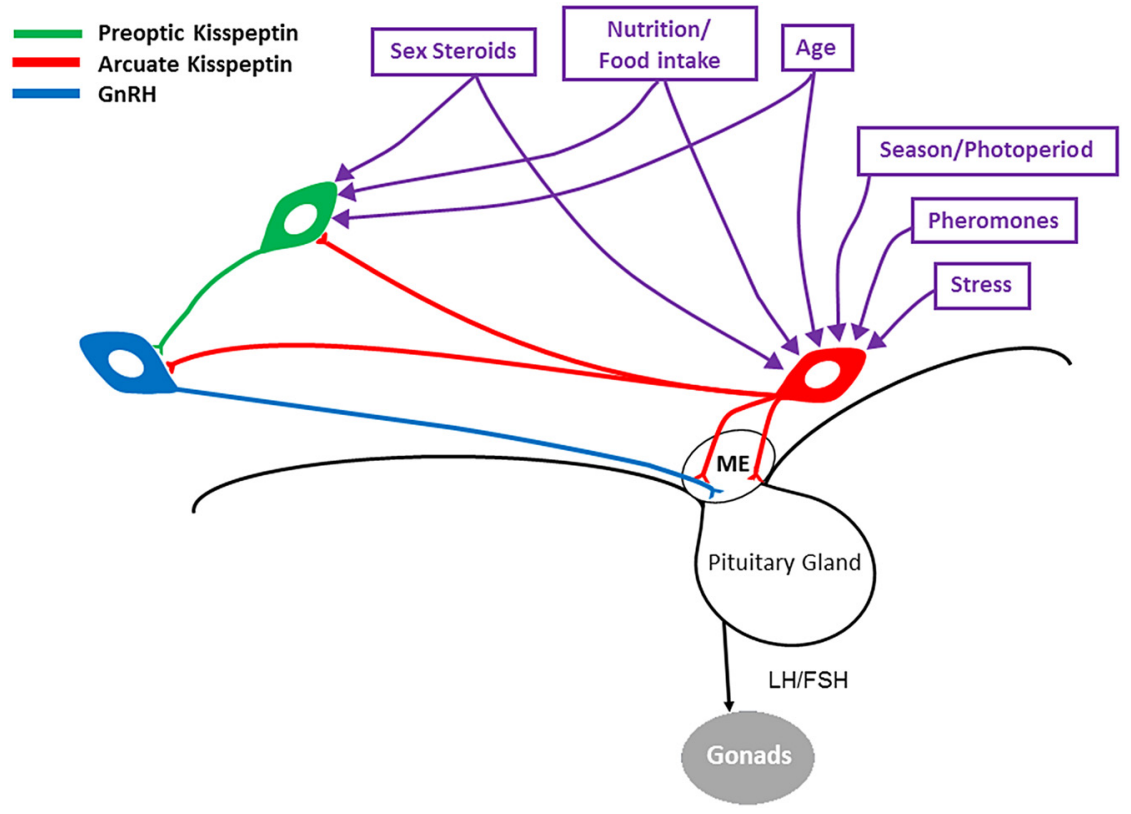

Figure 1

A model for the integration of factors from the internal and external environment in the brain control of reproduction in domestic animals. These factors are integrated by KNDy neurons in the arcuate nucleus, and the kisspeptin neurons in the rostral hypothalamus. These neurons then input to the $\mathrm{GnRH}$ neurons at the terminals in the median eminence and also at the cell bodies/ dendrites to regulate $\mathrm{GnRH}$ secretion into the hypophyseal portal vasculature. In addition, kisspeptin is released in to the portal vasculature itself, where it may directly regulate gonadotroph secretion. 
the evidence is very strong that kisspeptin exerts a role in the regulation of GnRH and LH secretion in domestic animals, most likely influencing both the generation of GnRH pulses, as well as the preovulatory LH surge. This action occurs at the median eminence to influence the release of GnRH into the hypophyseal portal vasculature. In addition, it may also act on GnRH cell bodies and dendrites, as well as at the anterior pituitary gland although the evidence is less strong. At least part of this action is a direct one, with kisspeptin fibres making contact with GnRH neurons. In doing so, the kisspeptin neurons integrate a lot of information about the internal and external environment of the animals. As such, it is possible that the kisspeptin neuronal network is the true controller of the reproductive system, with the GnRH neurons being the primary output signal from the brain.

\section{Declaration of interest}

The authors declare that there is no conflict of interest that could be perceived as prejudicing the impartiality of this review.

\section{Funding}

Original unpublished work cited in this review was funded by Charles Sturt University.

\section{Author contribution statement}

C J S drafted the manuscript. C J S, J L R, A J G and B M M all contributed to the revision of the manuscript.

\section{References}

Ahn T, Fergani C, Coolen LM, Padmanabhan V \& Lehman MN 2015 Prenatal testosterone excess decreases neurokinin 3 receptor immunoreactivity within the arcuate nucleus KNDy cell population. Journal of Neuroendocrinology 27 100-110. (https://doi.org/10.1111/ jne.12244)

Akhtar R, Shah S \& Qureshi I 2017 Effect of kisspeptin-10, LH and hCG on serum testosterone concentrations in stallions, donkeys and mules. Theriogenology 102 75-79. (https://doi.org/10.1016/j. theriogenology.2017.07.027)

Amstalden M, Coolen LM, Hemmerle AM, Billings HJ, Connors JM, Goodman RL \& Lehman MN 2010 Neurokinin 3 receptor immunoreactivity in the septal region, preoptic area and hypothalamus of the female sheep: colocalisation in neurokinin $\mathrm{B}$ cells of the arcuate nucleus but not in gonadotrophin-releasing hormone neurones. Journal of Neuroendocrinology 22 1-12. (https:// doi.org/10.1111/j.1365-2826.2009.01930.x)

Backholer K, Smith J \& Clarke IJ 2009 Melanocortins may stimulate reproduction by activating orexin neurons in the dorsomedial hypothalamus and kisspeptin neurons in the preoptic area of the ewe. Endocrinology 150 5488-5497. (https://doi.org/10.1210/en.2009-0604)
Backholer K, Smith JT, Rao A, Pereira A, Iqbal J, Ogawa S, Li Q \& Clarke IJ 2010 Kisspeptin cells in the ewe brain respond to leptin and communicate with neuropeptide $\mathrm{Y}$ and proopiomelanocortin cells Endocrinology 151 2233-2243. (https://doi.org/10.1210/en.2009-1190)

Blache D, Fabre-Nys CJ \& Venier G 1991 Ventromedial hypothalamus as a target for estradiol action on proceptivity, receptivity and luteinizinghormone surge of the ewe. Brain Research Bulletin 546 241-249. (https://doi.org/10.1016/0006-8993(91)91488-M)

Blache D, Fabre-Nys C \& Venier G 1996 Inhibition of sexual behaviour and the luteinizing hormone surge by intracerebral progesterone implants in the female sheep. Brain Research 741 117-122. (https:// doi.org/10.1016/S0006-8993(96)00907-9)

Blache D, Tjondronegoro S, Blackberry MA, Anderson ST, Curlewis JD \& Martin GB 1997 Gonadotrophin and prolactin secretion in castrated male sheep following subcutaneous or intracranial treatment with testicular hormones. Endocrine 7 235-243. (https://doi.org/10.1007/ BF02778146)

Briant C, Schneider J, Guillaume D, Ottogalli M, Duchamp G, Bruneau G \& Caraty A 2006 Kisspeptin induces ovulation in cycling Welsh pony mares. Animal Reproduction Science 94 217-219. (https://doi. org/10.1016/j.anireprosci.2006.04.021)

Caraty A, Fabre-Nys CJ, Delaleu B, Locatelli A, Bruneau G, Karsch FJ \& Herbison A 1998 Evidence that the mediobasal hypothalamus is the primary site of action of estradiol in inducing the preovulatory gonadotropin releasing hormone surge in the ewe. Endocrinology 139 1752-1760. (https://doi.org/10.1210/endo.139.4.5904)

Caraty A, Smith JT, Lomet D, Ben Saïd S, Morrissey A, Cognie J, Doughton B, Baril G, Briant C \& Clarke IJ 2007 Kisspeptin synchronizes preovulatory surges in cyclical ewes and causes ovulation in seasonally acyclic ewes. Endocrinology 148 5258-5267. (https://doi.org/10.1210/en.2007-0554)

Caraty A, Franceschini I \& Hoffman GE 2010 Kisspeptin and the preovulatory gonadotrophin-releasing hormone/luteinising hormone surge in the ewe: basic aspects and potential applications in the control of ovulation. Journal of Neuroendocrinology 22 710-715. (https://doi.org/10.1111/j.1365-2826.2010.02022.x)

Caraty A, Decourt C, Briant C \& Beltramo M 2012 Kisspeptins and the reproductive axis: potential applications to manage reproduction in farm animals. Domestic Animal Endocrinology 43 95-102. (https://doi. org/10.1016/j.domaniend.2012.03.002)

Caraty A, Lomet D, Sébert M, Guillaume D, Beltramo M \& Evans NP 2013 Gonadotrophin-releasing hormone release into the hypophyseal portal blood of the ewe mirrors both pulsatile and continuous intravenous infusion of kisspeptin: an insight into kisspeptin's mechanism of action. Journal of Neuroendocrinology 25 537-546. (https://doi.org/10.1111/jne.12030)

Cardoso RC, Alves BRC, Sharpton SM, Williams GL \& Amstalden M 2015 Nutritional programming of accelerated puberty in heifers: involvement of pro-opiomelanocortin neurones in the arcuate nucleus. Journal of Neuroendocrinology 27 647-657. (https://doi. org/10.1111/jne.12291)

Cernea M, Padmanabhan V, Goodman RL, Coolen LM \& Lehman MN 2015 Prenatal testosterone treatment leads to changes in the morphology of KNDy neurons, their inputs, and projections to $\mathrm{GnRH}$ cells in female sheep. Endocrinology 156 3277-3291. (https://doi. org/10.1210/en.2014-1609)

Chagas LM, Bass JJ, Blache D, Burke CR, Kay JK, Lindsay DR, Lucy MC, Martin GB, Meier S, Rhodes FM, et al. 2007 Invited Review: New perspectives on the roles of nutrition and metabolic priorities in the subfertility of high-producing dairy cows1. Journal of Dairy Science $\mathbf{9 0}$ 4022-4032. (https://doi.org/10.3168/jds.2006-852)

Chalivoix S, Bagnolini A, Caraty A, Cognié J, Malpaux B \& Dufourny L 2010 Effects of photoperiod on kisspeptin neuronal populations of the ewe diencephalon in connection with reproductive function. Journal of Neuroendocrinology 22 110-118. (https://doi.org/10.1111/ j.1365-2826.2009.01939.x 
Cheng G, Coolen LM, Padmanabhan V, Goodman RL \& Lehman MN 2010 The kisspeptin/neurokinin B/dynorphin (KNDy) cell population of the arcuate nucleus: sex differences and effects of prenatal testosterone in sheep. Endocrinology 151 301-311. (https://doi. org/10.1210/en.2009-0541)

Clarke IJ \& Cummins JT 1982 The temporal relationship between gonadotropin releasing hormone $(\mathrm{GnRH})$ and luteinizinf hormone (LH) secretion in ovariectomised ewes. Endocrinology 111 1737-1739. (https://doi.org/10.1210/endo-111-5-1737)

Clarke IJ, Li Q, Henry BA \& Millar RP 2018 Continuous kisspeptin restores luteinizing hormone pulsatility following cessation by a neurokinin B antagonist in female sheep. Endocrinology 159 639-646. (https://doi.org/10.1210/en.2017-00737)

De Bond J-AP \& Smith JT 2014 Kisspeptin and energy balance in reproduction. Reproduction 147 R53-R63. (https://doi.org/10.1530/ REP-13-0509)

De Bond J-AP, Li Q, Millar RP, Clarke IJ \& Smith JT 2013 Kisspeptin signaling is required for the luteinizing hormone response in anestrous ewes following the introduction of males. PLOS ONE $\mathbf{8}$ e57972. (https://doi.org/10.1371/journal.pone.0057972)

Decourt C, Tillet Y, Caraty A, Franceschini I \& Briant C 2008 Kisspeptin immunoreactive neurons in the equine hypothalamus: interactions with GnRH neuronal system. Journal of Chemical Neuroanatomy 36 131-137. (https://doi.org/10.1016/j.jchemneu.2008.07.008)

Decourt C, Caraty A, Briant C, Guillaume D, Lomet D, Chesneau D, Lardic L, Duchamp G, Reigner F \& Monget P 2014 Acute injection and chronic perfusion of kisspeptin elicit gonadotropins release but fail to trigger ovulation in the mare. Biology of Reproduction 9036. (https://doi.org/10.1095/biolreprod.113.114157)

Decourt C, Anger K, Robert V, Lomet D, Bartzen-Sprauer J, Caraty A, Dufourny L, Anderson G \& Beltramo M 2015 No evidence that RFamide related peptide 3 directly modulates LH secretion in the ewe. Endocrinology 157 1566-1575. (https://doi.org/10.1210/en.20151854)

Delgadillo JA, Gelez H, Ungerfeld R, Hawken PR \& Martin GB 2009 The 'male effect'in sheep and goats-revisiting the dogmas. Behavioural Brain Research 200 304-314. (https://doi.org/10.1016/j. bbr.2009.02.004)

Dufourny L \& Skinner DC 2002 Type II glucocorticoid receptors in the ovine hypothalamus: distribution, influence of estrogen and absence of co-localization with GnRH. Brain Research 946 79-86. (https://doi. org/10.1016/S0006-8993(02)02829-9)

Dufourny L, Caraty A, Clarke IJ, Robinson JE \& Skinner DC 2005 Progesterone-receptive $\beta$-endorphin and dynorphin B neurons in the arcuate nucleus project to regions of high gonadotropinreleasing hormone neuron density in the ovine preoptic area. Neuroendocrinology 81 139-149. (https://doi.org/10.1159/000086527)

Dufourny L, Gennetay D, Martinet S, Lomet D \& Caraty A 2015 The content of thyroid hormone receptor alpha in ewe kisspeptin neurons is not season-dependent. Journal of Neuroendocrinology $\mathbf{2 8} 12344$. (https://doi.org/ 10.1111/jne.12344)

Einarsson S, Brandt Y, Lundeheim N \& Madej A 2008 Stress and its influence on reproduction in pigs: a review. Acta Veterinaria Scandinavica 50 48-48. (https://doi.org/10.1186/1751-0147-50-48)

Estrada KM, Clay CM, Pompolo S, Smith JT \& Clarke IJ 2006 Elevated KiSS-1 expression in the arcuate nucleus prior to the cyclic preovulatory gonadotrophin-releasing hormone/lutenising hormone surge in the ewe suggests a stimulatory role for kisspeptin in oestrogen-positive feedback. Journal of Neuroendocrinology 18 806-809. (https://doi.org/10.1111/j.1365-2826.2006.01485.x)

Ezzat AA, Saito H, Sawada T, Yaegashi T, Yamashita T, Hirata T, Sawai K $\&$ Hashizume T 2009 Characteristics of the stimulatory effect of kisspeptin-10 on the secretion of luteinizing hormone, folliclestimulating hormone and growth hormone in prepubertal male and female cattle. Journal of Reproduction and Development 55 650-654. (https://doi.org/10.1262/jrd.20255)
Ezzat AA, Pereira A \& Clarke IJ 2015 Kisspeptin is a component of the pulse generator for GnRH secretion in female sheep but not THE pulse generator. Endocrinology 156 1828-1837. (https://doi. org/10.1210/en.2014-1756)

Fergani C, Routly JE, Jones DN, Pickavance L, Smith R \& Dobson H 2017 KNDy neurone activation prior to the LH surge of the ewe is disrupted by LPS. Reproduction 154 181-192. (https://doi.org/10.1530/ REP-17-0173)

Foradori CD, Coolen LM, Fitzgerald ME, Skinner DC, Goodman RL \& Lehman MN 2002 Colocalization of progesterone receptors in parvicellular dynorphin neurons of the ovine preoptic area and hypothalamus. Endocrinology 143 4366-4374. (https://doi. org/10.1210/en.2002-220586)

Foradori CD, Goodman RL \& Lehman MN 2005 Distribution of preprodynorphin mRNA and dynorphin-a immunoreactivity in the sheep preoptic area and hypothalamus. Neuroscience 130 409-418. (https://doi.org/10.1016/j.neuroscience.2004.08.051)

Foradori CD, Amstalden M, Goodman RL \& Lehman MN 2006 Colocalisation of dynorphin A and neurokinin B immunoreactivity in the arcuate nucleus and median eminence of the sheep. Journal of Neuroendocrinology 18 534-541. (https://doi.org/10.1111/j.13652826.2006.01445.x)

Franceschini I, Lomet D, Cateau M, Delsol G, Tillet Y \& Caraty A 2006 Kisspeptin immunoreactive cells of the ovine preoptic area and arcuate nucleus co-express estrogen receptor alpha. Neuroscience Letters 401 225-230. (https://doi.org/10.1016/j.neulet.2006.03.039)

Geschwind II, Dewey R, Hughes JP, Evans JW \& Stabenfeldt GH 1975 Plasma LH levels in the mare during the oestrous cycle. Journal of Reproduction and Fertility. Supplements 23 207-212.

Goodman RL, Coolen LM, Anderson GM, Hardy SL, Valent M, Connors JM, Fitzgerald ME \& Lehman MN 2004 Evidence that dynorphin plays a major role in mediating progesterone negative feedback on gonadotropin-releasing hormone neurons in sheep. Endocrinology 145 2959-2967. (https://doi.org/10.1210/en.2003-1305)

Goodman RL, Lehman MN, Smith JT, Coolen LM, de Oliveira CV, Jafarzadeh Shirazi MR, Pereira A, Iqbal J, Caraty A, Ciofi P, et al. 2007 Kisspeptin neurons in the arcuate nucleus of the ewe express both dynorphin A and neurokinin B. Endocrinology 148 5752-5760. (https://doi.org/10.1210/en.2007-0961)

Goodman RL, Jansen HT, Billings HJ, Coolen LM \& Lehman MN 2010 Neural systems mediating seasonal breeding in the ewe. Journal of Neuroendocrinology 22 674-681. (https://doi.org/10.1111/j.13652826.2010.02014.x)

Goodman RL, Maltby MJ, Millar RP, Hileman SM, Nestor CC, Whited B, Tseng AS, Coolen LM \& Lehman MN 2012 Evidence that dopamine acts via kisspeptin to hold GnRH pulse frequency in check in anestrous ewes. Endocrinology 153 5918-5927. (https://doi. org/10.1210/en.2012-1611)

Goodman RL, Hileman SM, Nestor CC, Porter KL, Connors JM, Hardy SL, Millar RP, Cernea M, Coolen LM \& Lehman MN 2013 Kisspeptin, neurokinin $\mathrm{B}$, and dynorphin act in the arcuate nucleus to control activity of the GnRH pulse generator in ewes. Endocrinology 154 4259-4269. (https://doi.org/10.1210/en.2013-1331)

Gottsch ML, Cunningham MJ, Smith JT, Popa SM, Acohido BV, Crowley WF, Seminara S, Clifton DK \& Steiner RA 2004 A role for kisspeptins in the regulation of gonadotropin secretion in the mouse. Endocrinology 145 4073-4077. (https://doi.org/10.1210/en.2004-0431)

Goubillon M, Forsdike RA, Robinson JE, Ciofi P, Caraty A \& Herbison A 2000 Identification of neurokinin B-expressing neurons as an highly estrogen-receptive, sexually dimorphic cell group in the ovine arcuate nucleus. Endocrinology 141 4218-4225. (https://doi.org/10.1210/ endo.141.11.7743)

Hanon EA, Lincoln GA, Fustin J, Dardente H, Masson-Pévet M, Morgan PJ \& Hazlerigg DG 2008 Ancestral TSH mechanism signals summer in a photoperiodic mammal. Current Biology 18 1147-1152. (https://doi. org/10.1016/j.cub.2008.06.076) 
Hashizume T, Saito H, Sawada T, Yaegashi T, Ezzat AA, Sawai K \& Yamashita T 2010 Characteristics of stimulation of gonadotropin secretion by kisspeptin-10 in female goats. Animal Reproduction Science 118 37-41. (https://doi.org/10.1016/j.anireprosci.2009.05.017)

Hassaneen A, Naniwa Y, Suetomi Y, Matsuyama S, Kimura K, Ieda N, Inoue N, Uenoyama Y, Tsukamura H, Maeda KI, et al. 2016 Immunohistochemical characterization of the arcuate kisspeptin/ neurokinin B/dynorphin (KNDy) and preoptic kisspeptin neuronal populations in the hypothalamus during the estrous cycle in heifers. Journal of Reproduction and Development 62 471-477. (https://doi. org/10.1262/jrd.2016-075)

Hawken PAR \& Martin GB 2012 Sociosexual stimuli and gonadotropinreleasing hormone/luteinizing hormone secretion in sheep and goats. Domestic Animal Endocrinology 43 85-94. (https://doi.org/10.1016/j. domaniend.2012.03.005)

Hoffman G, Le WW, Franceschini I, Caraty A \& Advis JP 2011 Expression of fos and in vivo median eminence release of LHRH identifies an active role for preoptic area kisspeptin neurons in synchronized surges of LH and LHRH in the ewe. Endocrinology 152 214-222. (https://doi.org/10.1210/en.2010-0066)

Ieda N, Uenoyama Y, Tajima Y, Nakata T, Kano M, Naniwa Y, Watanabe Y, Minabe S, Tomikawa J, Inoue N, et al. 2014 KISS1 gene expression in the developing brain of female pigs in pre- and peripubertal periods. Journal of Reproduction and Development $60312-316$. (https://doi. org/10.1262/jrd.2013-129)

Iqbal J, Pompolo S, Sakurai T \& Clarke IJ 2001 Evidence that orexincontaining neurones provide direct input to gonadotropinreleasing hormone neurones in the ovine hypothalamus. Journal of Neuroendocrinology 13 1033-1041. (https://doi.org/10.1046/j.13652826.2001.00719.x)

Jafarzadeh Shirazi MR, Zamiri MJ, Salehi MS, Moradi S, Tamadon A, Namavar MR, Akhlaghi A, Tsutsui K \& Caraty A 2014 Differential expression of RFamide-related peptide, a mammalian gonadotrophininhibitory hormone orthologue, and kisspeptin in the hypothalamus of Abadeh ecotype does during breeding and anoestrous seasons. Journal of Neuroendocrinology 26 186-194. (https://doi.org/10.1111/jne.12137)

Jansen HT, Cutter C, Hardy S, Lehman MN \& Goodman RL 2003 Seasonal plasticity within the gonadotropin-releasing hormone (GnRH) system of the ewe: changes in identified GnRH inputs and glial association. Endocrinology 144 3663-3676. (https://doi.org/10.1210/en.2002-0188)

Kadokawa H, Matsui M, Hayashi K, Matsunaga N, Kawashima C, Shimizu T, Kida K \& Miyamoto A 2008 Peripheral administration of kisspeptin-10 increases plasma concentrations of GH as well as LH in prepubertal Holstein heifers. Journal of Endocrinology 196 331-334. (https://doi.org/10.1677/JOE-07-0504)

Kirkwood RN, Forbes JM \& Hughes PE 1981 Influence of boar contact on attainment of puberty in gilts after removal of the olfactory bulbs. Journal of Reproduction and Fertility 61 193-196. (https://doi. org/10.1530/jrf.0.0610193)

Lehman MN, Robinson JE, Karsch FJ \& Silverman A-J 1986 Immunocytochemical localization of luteinizing hormone-releasing hormone (LHRH) pathways in the sheep brain during anestrus and the mid-luteal phase of the estrous cycle. Journal of Comparative Neurology 244 19-35. (https://doi.org/10.1002/cne.902440103)

Lehman MN, Karsch FJ \& Silverman A 1988 Potential sites of interaction between catecholamines and LHRH in the sheep brain. Brain Research Bulletin 20 49-58. (https://doi.org/10.1016/0361-9230(88)90008-1)

Lehman MN, Coolen LM \& Goodman RL 2010a Minireview: kisspeptin/ neurokinin B/dynorphin (KNDy) cells of the arcuate nucleus: a central node in the control of gonadotropin-releasing hormone secretion. Endocrinology 151 3479-3489. (https://doi.org/10.1210/ en.2010-0022)

Lehman MN, Merkley CM, Coolen LM \& Goodman RL 2010b Anatomy of the kisspeptin neural network in mammals. Brain Research Bulletin 1364 90-102. (https://doi.org/10.1016/j.brainres.2010.09.020)
Lents CA, Heidorn NL, Barb CR \& Ford JJ 2008 Central and peripheral administration of kisspeptin activates gonadotropin but not somatotropin secretion in prepubertal gilts. Reproduction 135 879-887. (https://doi.org/10.1530/REP-07-0502)

Li Q, Rao A, Pereira A, Clarke IJ \& Smith JT 2011 Kisspeptin cells in the ovine arcuate nucleus express prolactin receptor but not melatonin receptor. Journal of Neuroendocrinology 23 871-882. (https://doi. org/10.1111/j.1365-2826.2011.02195.x)

Li Q, Roa A, Clarke IJ \& Smith JT 2012 Seasonal variation in the gonadotropin-releasing hormone response to kisspeptin in sheep: possible kisspeptin regulation of the kisspeptin receptor. Neuroendocrinology 96 212-221. (https://doi.org/10.1159/000335998)

Li Q, Millar RP, Clarke IJ \& Smith JT 2015 Evidence that neurokinin B controls basal gonadotropin-releasing hormone secretion but is not critical for estrogen-positive feedback in sheep. Neuroendocrinology 101 161-174. (https://doi.org/10.1159/000377702)

Lopez JA, Bedenbaugh MN, McCosh RB, Weems PW, Meadows LJ, Wisman B, Coolen LM, Goodman RL \& Hileman SM 2016 Does dynorphin play a role in the onset of puberty in female sheep? Journal of Neuroendocrinology 28. (https://doi.org/10.1016/j. psyneuen.2016.07.080)

Louis GW, Greenwald-Yarnell M, Phillips R, Coolen LM, Lehman MN \& Myers MG Jr 2011 Molecular mapping of the neural pathways linking leptin to the neuroendocrine reproductive axis. Endocrinology 152 2302-2310. (https://doi.org/10.1210/en.2011-0096)

Magee C, Foradori CD, Bruemmer JE, Arreguin-Arevalo JA, McCue PM, Handa RJ, Squires EL \& Clay CM 2009 Biological and anatomical evidence for kisspeptin regulation of the hypothalamic-pituitarygonadal axis of estrous horse mares. Endocrinology 150 2813-2821. (https://doi.org/10.1210/en.2008-1698)

Martin GB, Blache D, Miller DW \& Vercoe PE 2010 Interactions between nutrition and reproduction in the management of the mature male ruminant. Animal 4 1214-1226. (https://doi.org/10.1017/ S1751731109991674)

Matsuda F, Nakatsukasa K, Suetomi Y, Naniwa Y, Ito D, Inoue N, Wakabayashi Y, Okamura H, Maeda K-I, Uenoyama Y, et al. 2015 The luteinising hormone surge-generating system is functional in male goats as in females: involvement of kisspeptin neurones in the medial preoptic area. Journal of Neuroendocrinology 27 57-65. (https://doi. org/10.1111/jne.12235)

Matsuyama S, Ohkura S, Mogi K, Wakabayashi Y, Mori Y, Tsukamura H, Maeda KI, Ichikawa M \& Okamura H 2011 Morphological evidence for direct interaction between kisspeptin and gonadotropin-releasing hormone neurons at the median eminence of the male goat: an immunoelectron microscopic study. Neuroendocrinology 94 323-332. (https://doi.org/10.1159/000331576)

McGrath BM 2015 Characterisation of the neuroanatomy of kisspeptin and RFRP-3 in the mare, and determination of the effect of kisspeptin on $L H$ release and ovulation. PhD Thesis. Charles Sturt University, Australia.

McGrath BM, Scott CJ, Wynn PC, Loy J \& Norman ST 2016 Kisspeptin stimulates LH secretion but not ovulation in mares during vernal transition. Theriogenology 86 1566-1572. (https://doi.org/10.1016/j. theriogenology.2016.05.016)

Merkley CM, Porter KL, Coolen LM, Hileman SM, Billings HJ, Drews S, Goodman RL \& Lehman MN 2012 KNDy (Kisspeptin/Neurokinin B/ Dynorphin) neurons are activated during both pulsatile and surge secretion of LH in the ewe. Endocrinology 153 5406-5414. (https://doi. org/10.1210/en.2012-1357)

Merkley CM, Coolen LM, Goodman RL \& Lehman MN 2015 Evidence for changes in numbers of synaptic inputs onto KNDy and GnRH neurones during the preovulatory LH surge in the ewe. Journal of Neuroendocrinology 27 624-635. (https://doi.org/10.1111/jne.12293)

Messager S, Chatzidaki EE, Ma D, Hendrick AG, Zahn D, Dixon J, Thresher RR, Malinge I, Lomet D, Carlton MB, et al. 2005 Kisspeptin directly stimulates gonadotropin-releasing hormone release via $\mathrm{G}$ https://joe.bioscientifica.com https://doi.org/10.1530/JOE-18-0485 (c) 2019 Society for Endocrinology Published by Bioscientifica Ltd. Printed in Great Britain 
protein-coupled receptor 54. PNAS 102 1761-1766. (https://doi. org/10.1073/pnas.0409330102)

Murata K, Wakabayashi Y, Sakamoto K, Tanaka T, Takeuchi Y, Mori Y \& Okamura H 2011 Effects of brief exposure of male pheromone on multiple-unit activity at close proximity to kisspeptin neurons in the goat arcuate nucleus. Journal of Reproduction and Development $\mathbf{5 7}$ 197-202. (https://doi.org/10.1262/jrd.10-070E)

Nestor CC, Briscoe AMS, Davis SM, Valent M, Goodman RL \& Hileman SM 2012 Evidence of a role for kisspeptin and neurokinin B in puberty of female sheep. Endocrinology 153 2756-2765. (https:// doi.org/10.1210/en.2011-2009)

Norgren RB \& Lehman MN 1989 A double-label pre-embedding immunoperoxidase technique for electron microscopy using diaminobenzidine and tetramethylbenzidine as markers. Journal of Histochemistry and Cytochemistry 37 1283-1289. (https://doi. org/10.1177/37.8.2666511)

Norman ST \& Larsen JE 2010 The Synchronisation of Oestrus and Ovulation in the Mare: Current Knowledge, Future Direction and a Practical Regimen. Canberra, Australia: Rural Industries Research and Development Corporation.

Ohkura S, Takase K, Matsuyama S, Mogi K, Ichimaru T, Wakabayashi Y, Uenoyama Y, Mori Y, Steiner RA, Tsukamura H, et al. 2009a Gonadotrophin-Releasing Hormone Pulse Generator Activity in the Hypothalamus of the Goat. Journal of Neuroendocrinology 21 813-821. (https://doi.org/10.1111/j.1365-2826.2009.01909.x)

Ohkura S, Takase K, Matsuyama S, Mogi K, Ichimaru T, Wakabayashi Y, Uenoyama Y, Mori Y, Steiner RA, Tsukamura H, et al. $2009 b$ Gonadotrophin-releasing hormone pulse generator activity in the hypothalamus of the goat. Journal of Neuroendocrinology 21 813-821. (https://doi.org/10.1111/j.1365-2826.2009.01909.x)

Ohkura S, Takase K, Wakabayashi Y, Yayou K, Uenoyama Y, Tsukamura H, Maeda K \& Okamura H 2010 Kisspeptin neurons in the hypothalamic arcuate nucleus are potent stimulators of GnRH/LH secretion in holstein steers. Biology of Reproduction $\mathbf{8 3}$ (Supplement 1) 576. (https://doi.org/10.1093/biolreprod/83.s1.576)

Okamura H, Yamamura T \& Wakabayashi Y 2013 Kisspeptin as a master player in the central control of reproduction in mammals: an overview of kisspeptin research in domestic animals. Journal of Animal Science 84 369-381. (https://doi.org/10.1111/asj.12056)

Okamura H, Yamamura T \& Wakabayashi Y 2017 Mapping of KNDy neurons and immunohistochemical analysis of the interaction between KNDy and substance P neural systems in goat. Journal of Reproduction and Development 63 571-580. (https://doi.org/10.1262/ jrd.2017-103)

Pillon D, Caraty A, Fabre-Nys C \& Bruneau G 2003 Short-term effect of oestradiol on neurokinin B mRNA expression in the infundibular nucleus of ewes. Journal of Neuroendocrinology 15 749-753. (https:// doi.org/10.1046/j.1365-2826.2003.01054.x)

Porter KL, Hileman SM, Hardy SL, Nestor CC, Lehman MN \& Goodman RL 2014 Neurokinin-3 receptor activation in the retrochiasmatic area is essential for the full pre-ovulatory luteinising hormone surge in ewes. Journal of Neuroendocrinology 26 776-784. (https://doi.org/10.1111/jne.12180)

Ralph CR, Lehman MN, Goodman RL \& Tilbrook AJ 2016 Impact of psychosocial stress on gonadotrophins and sexual behaviour in females: role for cortisol? Reproduction 152 R1-R14. (https://doi. org/10.1530/REP-15-0604)

Redmond JS, Baez-Sandoval GM, Spell KM, Spencer TE, Lents CA, Williams GL \& Amstalden M 2011a Developmental changes in hypothalamic Kiss1 expression during activation of the pulsatile release of luteinising hormone in maturing ewe lambs. Journal of Neuroendocrinology 23 815-822. (https://doi.org/10.1111/j.13652826.2011.02177.x)

Redmond JS, Macedo GG, Velez IC, Caraty A, Williams GL \& Amstalden M $2011 b$ Kisspeptin activates the hypothalamic- adenohypophyseal-gonadal axis in prepubertal ewe lambs. Reproduction 141 541-548. (https://doi.org/10.1530/REP-10-0467) Rose JL 2017 The role of RFRP-3 and Kisspeptin on GnRH secretion in the merino ram. PhD Thesis. Charles Sturt University, Australia.

Rose JL, Gunn AL \& Scott CJ 2018 Kisspeptin (Kp) and RFamiderelated peptide 3 (RFRP-3) neurons in the hypothalamus of dairy cattle; expression of oestrogen receptor alpha (ER $\alpha)$, and inputs to gonadotrophin releasing hormone ( $\mathrm{GnRH})$ neurons. In 49th Annual Scientific Meeting, Society for Reproductive Biology. Adelaide, SA, Australia.

Saito H, Sawada T, Yaegashi T, Goto Y, Jin J, Sawai K \& Hashizume T 2012 Kisspeptin-10 stimulates the release of luteinizing hormone and testosterone in pre-and post-pubertal male goats. Animal science journal 83 487-492. (https://doi.org/10.1111/j.17400929.2011.00978.x)

Sakamoto K, Murata K, Wakabayashi Y, Yayou K, Ohkura S, Takeuchi Y, Mori Y \& Okamura H 2012 Central administration of neurokinin $B$ activates kisspeptin/NKB neurons in the arcuate nucleus and stimulates luteinizing hormone secretion in ewes during the nonbreeding season. Journal of Reproduction and Development 58 700-706. (https://doi.org/10.1262/jrd.2011-038)

Sakamoto K, Wakabayashi Y, Yamamura T, Tanaka T, Takeuchi Y, Mori Y \& Okamura H 2013 A population of kisspeptin/neurokinin B neurons in the arcuate nucleus may be the central target of the male effect phenomenon in goats. PLOS ONE 8 e81017. (https://doi.org/10.1371/ journal.pone.0081017)

Scott CJ, Kuehl DE, Ferreira SA \& Jackson GL 1997 Hypothalamic sites of action for testosterone, dihydrotestosterone, and estrogen in the regulation of luteinizing hormone secretion in male sheep. Endocrinology 138 3686-3694. (https://doi.org/10.1210/ endo.138.9.5401)

Scott CJ, Pereira AM, Rawson JA, Simmons DM, Rossmanith WG, Ing NH \& Clarke IJ 2000a The distribution of progesterone receptor immunoreactivity and mRNA in the preoptic area and hypothalamus of the ewe: upregulation of progesterone receptor mRNA in the mediobasal hypothalamus by oestrogen. Journal of Neuroendocrinology 12 565-575. (https://doi.org/10.1046/j.1365-2826.2000.00490.x)

Scott CJ, Tilbrook AJ, Simmons DM, Rawson JA, Chu S, Fuller PJ, Ing NH $\&$ Clarke IJ 2000 $b$ The distribution of cells containing estrogen receptor-alpha (ERalpha) and ERbeta messenger ribonucleic acid in the preoptic area and hypothalamus of the sheep: comparison of males and females. Endocrinology 141 2951-2962. (https://doi. org/10.1210/endo.141.8.7622)

Sébert ME, Lomet D, Saïd SB, Monget P, Briant C, Scaramuzzi RJ \& Caraty A 2010 Insights into the mechanism by which kisspeptin stimulates a preovulatory LH surge and ovulation in seasonally acyclic ewes: potential role of estradiol. Domestic Animal Endocrinology 38 289-298. (https://doi.org/10.1016/j.domaniend.2010.01.001)

Smith JT 2008 Kisspeptin signalling in the brain: steroid regulation in the rodent and ewe. Brain Research Reviews 57 288-298. (https://doi. org/10.1016/j.brainresrev.2007.04.002)

Smith JT, Cunningham MJ, Rissman EF, Clifton DK \& Steiner RA 2005 Regulation of Kiss1 gene expression in the brain of the female mouse. Endocrinology 146 3686-3692. (https://doi.org/10.1210/en.2005-0488)

Smith JT, Clay CM, Caraty A \& Clarke IJ 2007 KiSS-1 messenger ribonucleic acid expression in the hypothalamus of the ewe is regulated by sex steroids and season. Endocrinology 148 1150-1157. (https://doi.org/10.1210/en.2006-1435)

Smith JT, Coolen LM, Kriegsfeld LJ, Sari IP, Jaafarzadehshirazi MR, Maltby M, Bateman K, Goodman RL, Tilbrook AJ, Ubuka T, et al. $2008 a$ Variation in kisspeptin and RFamide-related peptide (RFRP) expression and terminal connections to gonadotropin-releasing hormone neurons in the brain: a novel medium for seasonal breeding in the sheep. Endocrinology 149 5770-5782. (https://doi.org/10.1210/ en.2008-0581) 
Smith JT, Rao A, Pereira A, Caraty A, Millar RP \& Clarke IJ $2008 b$ Kisspeptin is present in ovine hypophysial portal blood but does not increase during the preovulatory luteinizing hormone surge: evidence that gonadotropes are not direct targets of kisspeptin in vivo. Endocrinology 149 1951-1959. (https://doi.org/10.1210/en.2007-1425)

Smith JT, Li Q, Pereira A \& Clarke IJ 2009a Kisspeptin neurons in the ovine arcuate nucleus and preoptic area are involved in the preovulatory luteinizing hormone surge. Endocrinology 150 5530-5538. (https://doi.org/10.1210/en.2009-0712)

Smith JT, Saleh SNH \& Clarke IJ 2009b Seasonal and cyclical change in the luteinizing hormone response to kisspeptin in the ewe. Neuroendocrinology 90 283-291. (https://doi.org/10.1159/000227806)

Smith JT, Li Q, Yap KS, Shahab M, Roseweir AK, Millar RP \& Clarke IJ 2011 Kisspeptin is essential for the full preovulatory LH surge and stimulates GnRH release from the isolated ovine median eminence. Endocrinology 152 1001-1012. (https://doi.org/10.1210/en.2010-1225)

Suzuki S, Kadokawa H \& Hashizume T 2008 Direct kisspeptin-10 stimulation on luteinizing hormone secretion from bovine and porcine anterior pituitary cells. Animal Reproduction Science $\mathbf{1 0 3}$ 360-365. (https://doi.org/10.1016/j.anireprosci.2007.05.016)

Tanaka T, Ohkura S, Wakabayashi Y \& Okamura H 2012 Effect of peripherally administered kisspeptin-10 on GnRH neurosecretion into the hypophyseal portal circulation in ovariectomized goat does. Small Ruminant Research 105 273-276. (https://doi.org/10.1016/j. smallrumres.2012.01.007)

Tanco VM, Whitlock BK, Jones MA, Wilborn RR, Brandebourg TD \& Foradori CD 2016 Distribution and regulation of gonadotropinreleasing hormone, kisspeptin, RF-amide related peptide-3, and dynorphin in the bovine hypothalamus. PeerJ 4 e1833. (https://doi. org/10.7717/peerj.1833)

Thrun LA, Dahl GE, Evans NP \& Karsch FJ 1997 A critical period for thyroid hormone action on seasonal changes in reproductive neuroendocrine function in the ewe. Endocrinology 138 3402-3409. (https://doi.org/10.1210/endo.138.8.5341)

Tilbrook AJ, Canny BJ, Serapiglia MD, Ambrose TJ \& Clarke IJ 1999 Suppression of the secretion of luteinizing hormone due to isolation/ restraint stress in gonadectomised rams and ewes is influenced by sex steroids. Journal of Endocrinology 160 469-481. (https://doi. $\operatorname{org} / 10.1677 /$ joe.0.1600469)

Tilbrook AJ, Turner AI \& Clarke IJ 2002 Stress and reproduction: central mechanisms and sex differences in non-rodent species. Stress $\mathbf{5}$ 83-100. (https://doi.org/10.1080/10253890290027912)

Tomikawa J, Homma T, Tajima S, Shibata T, Inamoto Y, Takase K, Inoue N, Ohkura S, Uenoyama Y, Maeda K, et al. 2010 Molecular characterization and estrogen regulation of hypothalamic Kiss1 gene in the pig. Biology of Reproduction 82 313-319. (https://doi. org/10.1095/biolreprod.109.079863)

Wagner GC, Johnston JD, Clarke IJ, Lincoln GA \& Hazlerigg DG 2007 Redefining the limits of day length responsiveness in a seasonal mammal. Endocrinology 149 32-39. (https://doi.org/10.1210/en.20070658)

Wakabayashi Y, Nakada T, Murata K, Ohkura S, Mogi K, Navarro VM, Clifton DK, Mori Y, Tsukamura H \& Maeda K 2010 Neurokinin
$\mathrm{B}$ and dynorphin $\mathrm{A}$ in kisspeptin neurons of the arcuate nucleus participate in generation of periodic oscillation of neural activity driving pulsatile gonadotropin-releasing hormone secretion in the goat. Journal of Neuroscience 30 3124-3132. (https://doi.org/10.1523/ JNEUROSCI.5848-09.2010)

Wakabayashi Y, Yamamura T, Sakamoto K, Mori Y \& Okamura H 2013 Electrophysiological and morphological evidence for synchronized GnRH pulse generator activity among kisspeptin/neurokinin B/ dynorphin a (KNDy) neurons in goats. Journal of Reproduction and Development 59 40-48. (https://doi.org/10.1262/jrd.2013-060)

Webster JR, Moenter SM, Barrell GK, Lehman MN \& Karsch FJ 1991 Role of the thyroid gland in seasonal reproduction. III. Thyroidectomy blocks seasonal suppression of gonadotropin-releasing hormone secretion in sheep. Endocrinology 129 1635-1643. (https://doi. org/10.1210/endo-129-3-1635)

Weems PW, Goodman RL \& Lehman MN 2015 Neural mechanisms controlling seasonal reproduction: principles derived from the sheep model and its comparison with hamsters. Frontiers in Neuroendocrinology 37 43-51. (https://doi.org/10.1016/j. yfrne.2014.12.002)

Weems PW, Witty CF, Amstalden M, Coolen LM, Goodman RL \& Lehman MN 2016 k-opioid receptor is colocalized in GnRH and KNDy cells in the female ovine and rat brain. Endocrinology 157 2367-2379. (https://doi.org/10.1210/en.2015-1763)

Weems PW, Smith J, Clarke IJ, Coolen LM, Goodman RL \& Lehman MN 2017 Effects of season and estradiol on KNDy neuron peptides, colocalization with D2 dopamine receptors, and dopaminergic inputs in the ewe. Endocrinology 158 831-841. (https://doi.org/10.1210/ en.2016-1830)

Weems PW, Coolen LM, Hileman SM, Hardy S, McCosh RB, Goodman RL \& Lehman MN 2018 Evidence that dynorphin acts upon kndy and GnRH neurons during gnrh pulse termination in the ewe. Endocrinology 159 3187-3199. (https://doi.org/10.1210/en.201800435)

Wright PJ \& Clarke IJ 1988 Pulsatile administration of gonadotrophinreleasing hormone stimulates, in oestrogen-treated anaesthetized ovariectomized ewes, a surge release of LH qualitatively and quantitatively different from that induced by oestradiol in conscious ovariectomized ewes. Journal of Endocrinology 116 143-148. (https:// doi.org/10.1677/joe.0.1160143)

Yamamura T, Wakabayashi Y, Sakamoto K, Matsui H, Kusaka M, Tanaka T, Ohkura S \& Okamura H 2014 The effects of chronic subcutaneous administration of an investigational kisspeptin analog, TAK-683, on gonadotropin-releasing hormone pulse generator activity in goats. Neuroendocrinology 100 250-264. (https://doi org/10.1159/000369819)

Yasuo S, Nakao N, Ohkura S, Iigo M, Hagiwara S, Goto A, Ando H, Yamamura T, Watanabe M, Watanabe T, et al. 2006 Long-day suppressed expression of type 2 deiodinase gene in the mediobasal hypothalamus of the saanen goat, a short-day breeder: implication for seasonal window of thyroid hormone action on reproductive neuroendocrine axis. Endocrinology 147 432-440. (https://doi. org/10.1210/en.2005-0507)

Received in final form 4 October 2018

Accepted 9 October 2018

Accepted Preprint published online 9 October 2018 https://joe.bioscientifica.com https://doi.org/10.1530/JOE-18-0485 (c) 2019 Society for Endocrinology Published by Bioscientifica Ltd. Printed in Great Britain 